\title{
DAMPAK SOSIAL EKONOMI PEMBANGUNAN WADUK JATIGEDE TERHADAP MASYARAKAT TANI DI KABUPATEN SUMEDANG (Suatu Kasus di Blok Pasirkanaga Desa Tarunajaya Kecamatan Darmaraja Kabupaten Sumedang)
}

\section{THE SOCIAL ECONOMIC IMPACT OF THE DEVELOPMENT OF JATIGEDE DAM TO THE FARMING SOCIETY IN SUMEDANG DISTRICT (A Case in the Pasirkanaga Block in Tarunajaya Village, Darmaraja District, Sumedang Regency)}

\author{
RONI FADLI ${ }^{*}$, TRISNA INSAN NOOR ${ }^{2}$, AGUS YUNIAWAN ISYANTO ${ }^{1}$ \\ ${ }^{1}$ Fakultas Pertanian Universitas Galuh \\ ${ }^{2}$ Fakultas Pertanian Universitas Padjajaran \\ EE-mail: ronifadli97@gmail.com
}

\begin{abstract}
ABSTRAK
Pembangungan Waduk Jatigede memiliki dampak antara lain dampak sosial, ekonomi dan biodiversivitas. Dampak sosial terjadi karena keinginan manusia untuk menyesuaikan diri dengan keadaan sekelilingnya ataupun disebabkan oleh ekologi. Tujuan penelitian untuk mengetahui: (1) Dampak sosial pembangunan Waduk Jatigede terhadap masyarakat tani di Kabupaten Sumedang, dan (2) Dampak ekonomi pembangunan Waduk Jatigede terhadap masyarakat tani di Kabupaten Sumedang. Sampel dalam penelitian ini diambil menggunakan sensus pada masyarakat tani di blok Pasirkanaga yang berjumlah 57 orang. Hasil menunjukan bahwa: (1) Dampak sosial berupa penurunan jumlah rumah permanen dan perubahan tradisi atau kebiasaan masyarakat, dan (2) Dampak ekonomi berupa perubahan mata pencaharian dari buruh tani menjadi tidak memiliki pekerjaan tetap atau buruh harian lepas, dan pemurunan pendapatan masyarakat.
\end{abstract}

Kata kunci: dampak sosial, dampak ekonomi, waduk jatigede

\begin{abstract}
Jatigede Dam development has impacts including social, economic and biodiversity impacts. Social impacts occur because of the human desire to adjust to the circumstances around it or caused by ecology. The purpose of this study was to determine: (1) The social impact of the development of the Jatigede Reservoir on the farming community in Sumedang Regency, and (2) The economic impact of the development of the Jatigede Reservoir on the farming community in the Sumedang Regency. The sample in this study was taken using a census in the farming community in the Pasiraga block totaling 57 people. The results show that: (1) social impacts in the form of a decrease in the number of permanent houses and changes in community traditions or habits, and (2) economic impacts in the form of changes in livelihoods from farm laborers to not having permanent jobs or casual daily laborers, and decreasing community income.
\end{abstract}

Keywords: social impact, economic impact, jatigede reservoir

\section{PENDAHULUAN}

Pembangunan adalah suatu proses perubahan di berbagai bidang kehidupan yang dilakukan secara sengaja berdasarkan suatu rencana tertentu. Pembangunan nasional di Indonesia, misalnya merupakan suatu proses perubahan berdasarkan rencana tertentu, dengan sengaja, dan memang dikehendaki, baik oleh pemerintah yang menjadi pelopor 
pembangunan, maupun masyarakat. Proses pembangunan terutama bertujuan untuk meningkatkan taraf hidup masyarakat, baik secara spiritual, maupun material (Soekanto, 2012).

Pembangunan pada hakihatnya bertujuan untuk meningkatkan kesejahteraan masyarakat dengan membangun berbagai saran dan aset penunjang dalam kehidupan bermasyarakat. Seiring dengan globalisasi, pembangunan dalam berbagai bidang pun terpacu untuk mampu besaing dengan tuntutan zaman. Pembangunan perekonomian yang ditandai dengan meningkatnya pendapatan per kapita, menurunkan tingkat pengangguran menunjukan kemajuan pembangunan di Indonesia yang patut untuk dibanggakan.

Salah satu yang termasuk ke dalam pembangunan yaitu infrastruktur, yang diartikan sebagai berbagai jenis bangunan yaitu jalan, terowongan, jembatan, kereta api, bandara, pelabuhan, kanal, kereta bawah tanah, bendungan, jaringan irigasi, pipa air, pabrik pemurnian air, selokan, dan lain-lain. Investasi infrastruktur memiliki dampak terhadap peningkatan produktivitas dan dapat memberikan kontribusi bagi pertumbuhan ekonomi masa depan di negara-negara berkembang dimana infrastruktur masih belum mencukupi. Infrastruktur yang baik membantu meningkatkan produktivitas dan menurunkan biaya dalam kegiatan ekonomi langsung yang produktif (Zultaqawa, 2017).

Salah satu pembangunan infrastruktur adalah investasi di bidang sumber daya seperti waduk atau bendungan, mengingat hal tersebut sangat dibutuhkan pada saat ini dalam rangka mendukung program ketahanan pangan nasional yang merupakan dasar bagi ketahanan ekonomi.

Waduk adalah tempat penampungan air super besar yang dibuat dengan membendung aliran sungai. Air yang ditampung kemudian dimanfaatkan untuk irigasi pertanian, pembangkit listrik, budidaya perikanan, bahan baku air minum, sarana olahraga air, sarana rekreasi, dan sebagainya. Kondisi alamnya yang indah, sehingga bisa dimanfaatkan sebagai pariwisata.

Pembangunan Waduk Jatigede merupakan strategi pemerintah untuk mengatasi kekeringan pada musim kemarau dan banjir pada musim penghujan. Waduk Jatigede ini juga direncanakan untuk dapat memberikan implikasi sebagai pengairan/irigasi bagi kawasan pertanian yang merupakan salah satu penyedia padi regional dan nasional, 
sebagai penyedia air bersih, sebagai penghasil energi listrik tenaga air, dan juga sebagai kawasan pariwisata. Terkait penyediaan air irigasi dan pengendalian banjir, karena Indonesia merupakan negara tropis dan memiliki curah hujan yang relatif besar namun tida merata. Jika air tersebut itu tidak dibendung, maka air akan mengalir begitu saja. Jika dibendung, oleh karna itu air dapat dimanfaatkan untuk keperluan sehari-hari dan sebagai penyedia air di musim kemarau (Fransisco, 2015).

Proses pembangunan Waduk Jatigede adalah sebuah perjalanan panjang yang pastinya memliki pro dan kontra. Pro dan kontra itu sendiri dimulai dari masyarakat eks area genangan Waduk Jatigede. Mengingat Kabupaten Sumedang adalah salah satu penyedia padi dalam skala nasiomal maupun regional, hal ini dipastikan tak lepas dari peran masyarakat terdampak Waduk Jatigede. Pro dan kontra ini disebabkan oleh adanya dampak positif dan negatif dari pembangunan Waduk Jatigede itu sendiri terhadap perekonomian masyarakat eks area genangan Waduk Jatigede dilihat dari produksi pertanian.

Pembangungan Waduk Jatigede memiliki dampak antara lain dampak sosial, ekonomi dan biodiversivitas. Dampak sosial terjadi karena keinginan manusia untuk menyesuaikan diri dengan keadaan sekelilingnya ataupun disebabkan oleh ekologi, dimana bahwa persoalan perubahan sosial adalah produk dari interaksi banyak faktor (Kusumaningrum, dkk, 2015). Dampak ekonomi berupa perubahan mata pencaharian, perubahan ini menuntut masyarakat terdampak untuk melakukan adaptasi sesuai dengan sumber daya yang ada. Warga terdampak genangan harus berkompetisi untuk dapat memanfaatkan waduk sebagai sarana untuk mampu bertahan hidup, air waduk yang saat ini berada di sekitar mereka dimafaatkan dalam bidang wisata atau ikan tangkapan, hal ini sesuai dengan batasan adaptasi yakni proses mengatasi halanganhalangan dari lingkungan dan proses perubahan-perubahan menyesuaikan dengan siuasi yang berubah (Soekanto, 2005). Dampak biodiversivitas adalah istilah yang menerangkan keanekaragaman, variabilitas, dan keunikan gen, spesies dan ekosistem dari mahluk hidup. Indonesia dikenal sebagai salah satu mega center keanekaragaman hayati dunia karena keberagaman habitat alaminya, kekayaan tumbuhan dan hewan serta banyaknya jumlah spesies endemik (Bappenas, 2003). 


\section{METODE PENELITIAN}

Penelitian ini menggunakan pendekatan kualitatif dimana hasil penelitian berisi kutipan kutipan dari datadata. Data-data ini mencakup transkrip wawancara, dokumen pribadi dan resmi, gambar, memo dan rekaman rekaman resmi lainnya (Emzir, 2012).

Penelitian dilaksanakan dengan menggunakan survai. Menurut Nazir (2011), metode survai adalah penyelidikan yang diadakan untuk mmendapatkan faktafakta dari gejala-gejala yang ada dan mencari keterangan-keterangan secara faktual, baik tentang institusi sosial, ekonomi, atau politik dari suatu daerah ataupun kelompok

Masyarakat tani di blok Pasir Kanaga Desa Tarunajaya Kecamatan Darmaraja Kabupaten Sumedang diambil secara sengaja (Purrposive Sampling) dengan pertimbangan merupakan masyarakat terdampak langsung dari pembangunan Waduk Jatigede. Menurut (Nasehudin dan Gozali, 2012), purposive sampling adalah sampel yang sengaja dipilih atas pertimbangan tertentu atau tidak acak.

Sampel dalam penelitian ini diambil menggunakan sensus, untuk keperluan data dalam penelitian ini seluruh masyarakat di blok Pasirkanaga dijadikan responden yaitu sebanyak 57 orang. Daniel (2002) mengemukakan bahwa metode sensus dikenal juga sebagai metode pencacah lengkap. Dengan semplingh semua individu yang ada dalam populasi dicacah sebagai responden.

Data yang digunakan dalam penelitian ini berupa data primer yang diperoleh melalui wawancara langsung ke responden dan data sekunder yang diperoleh dari dinas ataupun intansi yang berkaitan dengan penelitian. Proses analisis data dalam penelitian ini menggunakan model Miles dan Huberman (1984) dengan tahap sebagai berikut: Pengumpulan Data, Reduksi data, Penyajian Data, Penarikan Kesimpulan.

\section{Operasional Variabel}

Variabel yang digunakan dalam penelitian ini dioperasionalisasikan sebagai berikut:

1. Dampak pembangunan Waduk Jatigede adalah dampak sosial dan ekonomi pada masyarakat petani sebagai akibat pembangunan waduk.

2. Dampak sosial adalah dampak masyarakat petani sebagai akibat pembangunan Waduk Jatigede yang didekati dengan akses pendidikan, tempat tinggal, tradisi/kebiasaan dari masyarakat petani. 
3. Dampak ekonomi adalah dampak masyarakat petani sebagai akibat pembangunan Waduk Jatigede yang didekati dengan pendapatan dari usahatani dan pendapatan lainya.

4. Pendapatan usahatani adalah pendapatan petani dari usahatani yang di ukur dengan rupiah per tahun.

5. Pendapatan di luar usahatani adalah pendapatan yang diperoleh di luar dari usahatani di ukur dengan rupiah per tahun.

\section{HASIL DAN PEMBAHASAN}

\section{a. Identitas Responden}

Semua responden pada penelitian ini berada pada kategori usia produktif yaitu 15-65 tahun. Maka masyarakat masih mampu bekerja secara maksimal untuk memenuhi kebutuhan hidupnya. Sejalan dengan teori Mulyadi (2012) mendefinisikan tenaga kerja adalah penduduk dalam usia kerja (berusia 15- 64 tahun).

Masyarakat di blok Pasirkanaga yang menjadi responden dalam penelitian ini laki-laki sebanyak 45 orang $(78,95 \%)$, dan perempuan sebanyak 12 orang $(21,05 \%)$. Maka pada umumnya laki laki lebih produktif dalam bekerja dalam hal ini menunjukan 21,05\% kepala keluarga yaitu perempuan, diharapkan memberikan pandangan lain bagaimana perempuan menjadi seorang kepala keluargga.

Rendahnya tingkat pendidikan masyarakat di blok Pasirkanaga karena mayoritas penduduk adalah tamatan SD dan SMP dengan Jumlah 48 orang $(84,21 \%)$. Maka masyarakat blok Pasirkanaga tidak dapat memanfaatkan potensi yang ada karena kurangga pengalaman mengenai keahlian dan keterampilan sehingga berpengaruh pada kondisi ekonomi dan sosial. Dengan memiliki pendidikan yang cukup maka seseorang akan mengetahui mana yang baik dan mana yang dapat menjadikan seseorang menjadi berguna baik untuk dirinya sendiri maupun untuk orang lain yang membutuhkannya. Seperti yang dikemukakan Soekanto (2003) Pendidikan merupakan suatu alat yang akan membina dan mendorong seseorang untuk berfikir secara rasional maupun logis, dapat meningkatkan kesadaran untuk menggunakan waktu sebaik-baiknya seefektif dan seefisien mungkin dengan menyerap banyak pengalaman mengenai keahlian dan keterampilan sehingga menjadi cepat tanggap terhadap gejalagejala sosial yang terjadi.

Mayoritas 23 kepala keluarga $(40,36 \%)$ di blok Pasirkana memiliki jumlah tanggungan keluarga sebanyak tiga 
orang. Hal tersebut menunjukan masih sejalan dengan program pemerintah dengan manfaat meringankan tanggung jawab kepala keluarga untuk meghidupi kebutuhan keluarga antara lain kebutuhan untuk pangan dan non pangan, tingkat pendidikan keluarga, tingkat kesehatan keluarga dan kondisi serta fasilitas yang dimiliki dalam rumah tangga hal tersebut akan mempengaruhi pengeluaran rumah tangga.

\section{Pembangunan waduk Jatigede}

Pembangunan Waduk Jatigede merupakan pembangunan di bidang infrastuktur. Pembangunan ini turut mempengaruhi berubahnya sumberdaya dari semula sumberdaya lahan (terrestrial) menjadi sumberdaya air (aquatiq). Waduk ini dibangun dengan membendung aliran Sungai Cimanuk di wilayah Kecamatan Jatigede, secara fisik pembangunan waduk Jatigede menenggelamkan seluas 6.738 hektar tanah yang meliputi sawah, hutan, pemukiman warga, lading, kebun, dalam 28 desa di 5 kecamata antara lain kecamatan Jatinunggal, Situraja, wado, Tomo dan Darmaraja. Waduk Jatigede pada saat musim hujan dapat menampung air sebanyak 980 juta m3. Air hujan yang turun di daerah tangkapan air sebagian besar akan mengalir ke sungai-sungai, air itu dapat ditampung sehingga kemungkinan banjir dapat dikurangi dan pada musim kemarau air yang tertampung tersebut dapat dimanfaatkan untuk berbagai keperluan, antara lain untuk irigasi lahan pertanian, Pembangkit Listrik Tenaga Air (PLTA), Penyedia air bersih dan pariwisata bagi beberapa kabupaten yaitu Kabupaten Sumedang, Cirebon, Indramayu dan Majalengka.

\section{b. Dampak Sosial Pembangunan Waduk Jatigede}

\section{Akses Pendidikan}

Peneliti menemukan bahwa pembangunan waduk Jatigede tidak bepengaruh pada akses pendidikan, dikarenakan tempat tinggal masyarakat sebelumnya tidak jauh dari desa yang sekarang mereka tinggali, akses jalan desa tarunajaya adalah akses menuju desa Cibogo, dan sebelumnya mayoritas masyarakat di blok Pasirkanaga bertempat tinggal di desa tersebut. Dapat dibuktikan dengan hasil wawancara yang dapat dilihat pada Tabel 1. 
Tabel 1. Akses Pendidikan

\begin{tabular}{clcccc}
\hline No & Akses Pendidikan & Sebelum & Persentase $(\%)$ & Sesudah & Persentase (\%) \\
\hline 1 & Sulit Terjangkau & 5 & 8,78 & & \\
2 & Mudah Terjangkau & 52 & 91,22 & 17 & 29,82 \\
3 & Sangat Terjangkau & 0 & 0 & 40 & 70,18 \\
\hline & Jumlah & 57 & 100 & 57 & 100 \\
\hline
\end{tabular}

Sumber: Data Primer, 2019

Tabel 1 menunjukan bahwa akses pendidikan sebelum dan sesudah pembangunan waduk Jatigede tidak berpengaruh bagi masyarakat blok Pasirkanaga, hal itu dibuktikan dengan $70,18 \%$ jawaban responden sebelum ada pembangunan waduk jatigede menjawab sangat terjangkau, dan jika dibandingkan dengan sebelumnya sebanyak 91,22\% responden menjawab mudah terjangkau. Karena memang jarak dan sarana dapat di akses dengan mudah sehinga diharapkan dapat meningkatkan tingkat pendidikan anak-anak di blok Pasirkanaga supaya mereka menggunakan waktu sebaik- baiknya seefektif dan seefisien mungkin dengan menyerap banyak pengalaman mengenai keahlian dan keterampilan sehingga menjadi cepat tanggap terhadap gejala-gejala sosial dan dapat meningkat tarap hidup mereka

\section{Kondisi Tempat Tinggal}

Pembangun waduk Jatigede mengharuskan masyarakat meninggalkan tempat tinggal yang lama dan membuat tempat tinggal baru. Hal tersebut pasti akan mengakibatkan kondisi tempat tinggal responden mengalami perubahan. Sebagaimana dapat dilihat pada Tabel 2.

Tabel 2. Kondisi Tempat Tinggal

\begin{tabular}{clcccc}
\hline No & Kondisi Tempat Tinggal & Sebelum & Persentase (\%) & Sesudah & Persentase (\%) \\
\hline 1 & Permanen & 48 & 84,21 & 34 & 59,65 \\
2 & Semi Permanen & 6 & 10,53 & 15 & 26,32 \\
3 & Non Permanen & 3 & 5,26 & 8 & 14,03 \\
\hline & Jumlah & 57 & 100 & 57 & 100 \\
\hline
\end{tabular}

Sumber: Data Primer, 2019

Tabel 2 menunjukan adanya penurunan jumlah tempat tinggal permanen sebagai dampak dari pembangunan waduk Jatigede. Di sisi lain, tempat tinggal yang semi permanen dan non permanen mengalami peningkatan.
Di blok Pasirkanaga beberapa rumah yang tidak terlalu besar dihuni lebih dari satu kepala keluarga yang sebelumnya mempunyai tempat tinggal masing-masing seperti yang dialami bapak Aep dan keluarga, hal tersebut dikarenakan uang 
ganti rugi yang sedikit tidak cukup untuk membeli tanah dan membuat rumah baru sehingga mereka menggabungkan uang ganti rugi tersebut untuk membuat rumah mereka bersama.

Kondisi ini dijelaskan oleh bapak Sayim Hidayat sebagai berikut:

"kita kan rumah di sana gede cuman tidak diganti rugi, habisnya hanya dikasih uang pesangon kecil-kecilan 29 juta, aturan mah kompensasinya yang sesuai buat bikin rumah. Tadinya saya kira pementah itu mau ngasih uang sesuai aturan relokasi nyampe seratus lima puluh juta ternyata fakta di lapangan tidak gede hanya segitu, cuman ngasih santunan saja bukan ngasih biaya untuk membuat rumah"

Pada intinya meskipun kondisi tempat tingga mayoritas permanen tetapi terjadi perubahan-perubahan seperti yang dialami bapak Aep dan bapak Sayim Hidayat. Tempat tinggal adalah termasuk kebutuhan pokok bagi keluarga, perubahan keadaan tempat tingal sangat terasa berpengaruh bagi masyarakat sekitar sehingga pada hal ini konsep pembangunan yang seharusnya membuat hidup masyarakat lebih baik justru tidak ada pengaruh positif bagi masyarakat sekitar.

\section{Tradisi / Kebiasaan}

Selain harus meninggalkan tempat tinggal yang sudah lama mereka tempati, mereka juga harus kehilangan kebiasaan atau tradisi sebelumnya, antara lain penduduk blok Pasirkanaga tidak lagi merasakan tradisi atau kebiasaan mereka yaitu bertani, karena tidak lagi memiliki lahan garapan seperti sawah yang sekarang sudah berubah menjadi perairan waduk. Sebagian orang menjadi pencari ikan atau nelayan yang bermodal jala ikan yang tidak di barengi dengan pengalaman.

Ada beberapa situs yang terendam seperti makam peninggalan kerajaan Sumedang, hilangnya adat istiadat peninggalan budaya nenek moyang, yang meskipun tidak ada kaitan langsung dengan masyarakat di blok Pasirkanaga tetapi dirasakan oleh seluruh warga masyarakat yang kehilangan sebagian nilai budaya karena Kabupaten Sumedang dapat dikatakan pusat (puser) budaya Sunda. Sehingga hal ini menjadi sebuah keributan antara masyarakat dengan pemerintah karena masyarakat yang sangat mengghargai adanya budaya peninggalan yang ada.

\section{c. Dampak Ekonomi Pembangunan Waduk Jatigede}

\section{Jenis Pekerjaan}

Jenis pekerjaan atau sumber mata pencaharian, yaitu segala aktifitas masyarakat memberdayakan potensi 
sumberdaya alam yang nantinya terhadap jenis pekerjaan dapat dilihat pada berpengaruh bagi kesejahteraan keluarga. Tabel 3.

Dampak pembangunan waduk Jatigede

Tabel 3. Jenis Pekerjaan

\begin{tabular}{clcccc}
\hline No & Pekerjaan & Sebelum & Persentase $(\%)$ & Sesudah & Persentase (\%) \\
\hline 1 & Petani & 5 & 8,77 & 0 & \\
2 & Buruh Tani & 35 & 61,40 & 6 & 10,53 \\
3 & Buruh Bangunan & 4 & 7,02 & 2 & 3,52 \\
4 & Pedagang & 5 & 8,77 & 6 & 10,53 \\
5 & Nelayan & 0 & 0 & 6 & 10,53 \\
6 & Pegawai Swasta & 2 & 3,52 & 1 & 1,75 \\
7 & Buruh Harian Lepas & 5 & 8,77 & 32 & 56,14 \\
8 & Lainya & 1 & 1,75 & 4 & 7,02 \\
\hline & Jumlah & 57 & 100 & 57 & 100 \\
\hline
\end{tabular}

Sumber: Data Primer 2019

Tabel 9 menunjukan adanya perubahan jenis pekerjaan masyarakat tani sebelum pembangunan waduk jatigede adalah buruh tani sebanyak 35 orang (61,40\%), sedangkan setelah adanya pembangunan waduk mayoritas adalah sebagai buruh harian lepas sebanyak 32 orang $(56,14 \%)$. Hal tersebut disebabkan adanya kegiatan pembebasan lahan yang menimbulkan perubahan fungsi lahan pertanian menjadi lahan waduk, yang menimbulkan dampak lanjutan terhadap hilangnya lahan garapan penduduk baik petani pemilik maupun buruh tani.

Kondisi ini yang dirasakan oleh penduduk blok Pasirkanaga berupa hilangnya mata pencaharian, salah satunya yang dirasakan oleh bapak Samsudin yang memberikan pernyataan sebagai berikut.

\begin{abstract}
"sekarang saya kehilangan mata pencaharian karena tidak ada lagi lahan pertanian yang tadinya saya bisa menjadi buruh tani meskipun tidak seberapa tapi lumayan. Sekarang sulit malah tidak ada, jadi nelayan saya takut belum ada pengalaman, tidak ada modal untuk beli peralatan, jadi saya bingung harus seperti apa. Saya tahu sebagian orang yang punya modal bisa memanfaatkan jatigede, tapi saya karena keterbatasan dan kita yang sudah terbiasa dengan sawah susah mencari pekerjaan lagi karena tidak ada ilmunya selain menanam padi”
\end{abstract}

Masyarakat sadar adanya potensi pada waduk Jatigede yang bisa dijadikan mata pencaharian, tetapi karena masyarakat sudah terbiasa dengan bidang pertanian sangat sulit untuk berpindah pada bidang yang lain karena masyarakat merasa kurangnya pengalaman yang mereka miliki. Hal tersebut kontradiktif 
dengan teori pembangunan demi mencapai kehidupan yang serba lebih baik menurut Todaro (2000) Peningkatan standar hidup yang tidak hanya berupa peningkatan pendapatan tetapi juga meliputi penambahan penyediaan lapangan kerja, perbaikan kualitas pendidikan, serta peningkatan perhatian atas nilai nilai kultural dan kemanusiaan, yang kesemua itu tidak hanya untuk memperbaiki kesejahteraan materiil, melainkan juga menumbuhkan jati diri pribadi dan bangsa yang bersangkutan.
Pendapatan masyarakat tani merupakan pendapatan yang diperoleh sebelum dan sesudah adanya waduk Jatigede. Peneliti mengalami keterbatasan informasi pada pendapatan masyarakat blok Pasirkanaga karena hanya 51 dari 57 responden yang terbuka mengenai pendapatan dikarenakan responden mengalami kesulitan dalam menghitung pendapatan per bulan karena pendapatan responden tidak tetap atau tidak menentu. Pendapatan responden sebelum dan sesudah adanya pembangunan waduk Jatigede dapat dilihat pada Tabel 4.

\section{Pendapatan}

Tabel 4. Pendapatan responden

\begin{tabular}{clcccc}
\hline No & Pendapatan $(\mathrm{Rp})$ & Sebelum & Persentase $(\%)$ & Sesudah & Persentase $(\%)$ \\
\hline 1 & $\leq 700.000$ & 1 & 1,96 & 29 & 58,56 \\
2 & $800.0000-1.500 .000$ & 38 & 74,51 & 19 & 37,26 \\
3 & $1.600 .000-2.300 .000$ & 9 & 17,65 & 1 & 1,96 \\
4 & $2.400 .0000-3.000 .000$ & 3 & 5,88 & 2 & 3,92 \\
5 & $\geq 3.100 .000$ & 0 & 0 & 0 & 0 \\
\hline & Jumlah & 51 & 100 & 51 & 100 \\
\hline
\end{tabular}

Sumber: Data Primer 2019

Tabel 4 menunjukan mayoritas jumlah tertinggi pendapatan sebelum adanya waduk Jatigede adalah Rp. 800.000 - Rp. 1.500.000 sebanyak 38 orang $(74,51 \%)$, sedangkan mayoritas pendapatan tertinggi setelah adanya waduk Jatigede yaitu kurang dari Rp. 700.000 sebanyak 29 (58,56\%). Hal ini menunjukan adanya penurunan pendapatan masyarakat di blok Pasirkanaga yang disebabkan oleh hilangnya mata pencaharian semula dan sulitnya memperoleh mata pencaharian pengganti. Sulitnya mencari mata pencaharian tersebut membuat ibu Dewi berumur 64 tahun tidak lagi brkerja dan hanya mengandalkan anaknya untuk memenuhi kebutuhan hidup. Berikut pernyataan ibu :

"sekarang saya tidak bekerja karena tidak mendapatkan lahan garapan sawah jadi tidak mendapat 
penghasilan, untuk kehidupan sehari-hari saya hanya saya di kota, cukuplah untuk kehidupan sehari-hari, sekarang kerja pun mau kerja apa tidak ada yang saya bisa lakukan, kondisi badan pun sudah tidak kuat kerja berat karena saya sudah tua jadi saya sehari-hari hanya diam di rumah sama cucu saya"

Hilangnya mata pencaharian mempengaruhi pendapatan masyarakat blok Pasirkanaga dan mengurangi penghasilan untuk biaya kebutuhan hidup masyarakat sehingga mengharuskan anakanaknya yang menjadi tulang punggung keluarga. . Dan juga hal tersebut dapat meningkatkan angka kemiskinan maha tidak sejalan dengan teori pembangunan demi mencapai kehidupan yang serba lebih baik menurut Todaro (2000) Peningkatan ketersediaan serta perluasan distribusi berbagai macam barang kebutuhan hidup yang pokok, seperti pangan, sandang, papan, kesehatan dan perlindungan keamanan.

\section{KESIMPULAN DAN SARAN}

\section{Kesimpulan}

Dampak sosial pembangunan waduk Jatigede terhadap masyarakat tani di Kabupaten Sumedang berupa: (1) tidak ada dampak yang berarti pada akses pendidikan dimana $70,18 \%$ responden menjawab sebelum adanya pembangunan waduk jatigede sangat terjangkau. Setelah ada pembangunan tidak ada perubahan yang berarti, hal itu dibuktikan dengan 91,22\% responden menjawab mudah terjangkau, (2) adanya penurunan keaadaan rumah permanen sebanyak $24,56 \%$ dari sebelumnya $84,21 \%$ menjadi $59,65 \%$. Selain itu, ada peningkatan jumlah tempat tinggal semi permanen dan non permanen, dan (3) Tradisi atau kebiasaan asyarakat mengalami perubahan karena harus kehilangan tradisi kebiasaan bertani menjadi nelayan atau pun yang lainnya.

Dampak ekonomi pembangunan waduk Jatigede terhadap masyarakat tani di Kabupaten Sumedang berupa: (1) perubahan mata pencaharian yang semula $61,40 \%$ bekerja menjadi buruh tani menjadi $56,14 \%$ tidak memiliki pekerjaan tetap atau buruh harian lepas, dan (2) penurunan pendapata dari $74,51 \%$ memiliki pendapatan Rp.800.000Rp.1.500.000 menjadi 58,56\% berpenghasilan kurang dari Rp.700.000.

\section{Saran}

Perlu diadakannya kegiatan pendampingan, dan pelatihan kepada masyarakat yang terkena dampak untuk meningkatkan keterampilam yang mereka 
miliki agar dapat meningkatkan dan taraf hidup masyarakat.

Dalam pembinaan dan pemberdayaan masyarakat terdampak selain aspek ekonomi, dan sosial juga yang tak kalah pentingnya adalah pembinaan secara psikis, sehingga mereka memiliki mental yang kuat dalam menghadapi kenyataan yang terjadi dengan adanya waduk Jatigede.

Untuk masyarakat yang masih menganggur, berwirausaha merupakat alternatif yang baik untuk memperoleh pendapatan.

Potensi untuk berwirausaha di wilayah waduk Jatigede baik potensi SDM maupun potensi SDA masih cukup berlimpah untuk dimanfaatkan secara optimal.

\section{DAFTAR PUSTAKA}

Bappenas. (2003). Dokumen Nasional IBSAP. Jakarta

Daniel, MS. (2002). Metode Penelitian Sosial Ekonomi. PT Bumi Aksara. Jakarta

Emzir. 2012. Metodologi Penelitian Pendidikan:Kuantitatif dan Kualitatif. Rajawali Pers. Jakarta.
Fransisco, D. (2015). Dampak Kebijakan Dalam Pembangunan Waduk Jatigede. Jurnal Sosek Pekerjaan Umum, Vol.7 No.3, November 2015, hal $161-171$

Kusumaningrum, dkk. (2015). Social Quality Masyarakat Lahan Pasir Pantai pada Aspek Social Empowernment di Kecamatan Panjatan Kabupaten Kulonprogo. Jurnal Agriekonomika 4(1): 1-9. Vol 4, No 1: April 2015

Miles, M.B. dan Huberman,M.A. (1984) Qualitative Data Analysis, London

Mulyadi, S. 2012, Eknonomi Sumber Daya Manusia, Raja Grafindo Persada, Jakarta.

Nasehudin, dan Gozali. (2012). Metode Penelitian Kuantitatif: CV Pustaka Setia. Bandung.

Nazir, M. (2011). Metode penelitian. Ghalia Indonesia. Bogor.

Soekanto, S. (2012). Sosiologi Suatu Pengantar. Rajawali Pers. Jakarta

(2005). Sosiologi Suatu Pengantar. PT Raja Grafindo Persada. Jakarta. 2003. Memperkenalkan Sosiologi, Rajawali Press. Jakarta

Todaro, M.P. 2000. Pembangunan Ekonomi di Dunia Ketiga. Erlangga. Jakarta.

Zultaqawa, Z. (2017). Apakah ada Dampak Sosial-Ekonomi akibat Pembangunan Infrastruktur? Pengalaman dari Negara Lain. Jurnal UNIKOM 2(1), November 2017. 